\title{
Research Paper Impact of Bt technology on input use pattern of cotton cultivation in Punjab
}

\section{Shaminder Kumar and Sanjeev Kumar}

See end of the paper for authors' affiliations

Correspondence to :

Shaminder Kumar

Department of Social

Science, Dr. Y. S. Parmar

University of Horticulture and Forestry, Nauni, Solan (H.P.) India

Email : shaminderkumar $64 @$ gmail.com

Paper History :

Received : 02.01.2019;

Revised : 18.01.2019;

Accepted : 29.01.2019
ABSTRACT : The present study was conducted to analyze the inputs use of cotton cultivation in south-western districts of Punjab at two different points of time viz., 2001-02 and 2009-10. The crosssection data collected under centrally sponsored "Comprehensive scheme to study the cost of cultivation of principal crops in Punjab" from seven villages of different tehsils of south-western zone of Punjab having more than 50 per cent of the net sown area under cotton were taken for the study. The inputs use structure changed significantly during the two study years. During 2001-02, the major share $(62.29 \%)$ in total human labour was of family labour, followed by casual labour (30.74\%) and attached servant labour $(6.96 \%)$. While during 2009-10, the major share (46.73\%) was of human labour followed by casual labour $(46.06 \%)$ and attached servant labour $(7.21 \%)$. Due to higher yield advantage, picking in Bt cotton required more labour as this operation is done manually. So, mechanization of picking operation can provide solution to this problem. Adequate storage facility and credit facility will help the farmers to avoid distress sale during glut period and increase their income.

KEY WORDS : Bt-cotton, Plant protection, Cost of cultivation, Input use, Cost structure

How To Cite This PAPer : Kumar, Shaminder and Kumar, Sanjeev (2019). Impact of Bt technology on input use pattern of cotton cultivation in Punjab. Internat. Res. J. Agric. Eco. \& Stat., 10 (1) : 21-26, DOI : 10.15740/ HAS/IRJAES/10.1/21-26. Copyright@ 2019: Hind Agri-Horticultural Society. 